\title{
Conceptualization of a Predictive Model for Analysis of the Health Outcomes of Dust Events in a Society with Köppen Climate Classification BW
}

\author{
Estrella Molina-Herrera ${ }^{1}$, Alberto Ochoa ${ }^{2,3}$, Thomas Gill ${ }^{1}$, \\ Gabriel Ibarra-Mejia ${ }^{1}$, Carlos Herrera ${ }^{1}$ \\ ${ }^{1}$ University of Texas at El Paso, El Paso, TX, USA \\ ${ }^{2}$ The Autonomous University of Ciudad Juarez, Chihuahua, Mexico \\ ${ }^{3}$ El Paso VA Health Care System, TX, USA ${ }^{*}$
}

\begin{abstract}
High concentrations of particulate matter (PM) in the air during Dust Events (DEs) are silently impacting the health of people without their awareness. It has been demonstrated that exposure to increased levels of PM can increase the susceptibility to respiratory, circulatory, mental and other diseases due to inflammation. In addition, living in a city with Köppen climate classification type BW (arid) and subsequently with frequent high levels of PM could have a negative impact on the population's health. There are very few studies available in the southwestern United States pertaining to the associations between exposure to atmospheric aerosol after DEs and hospitalizations. Therefore, we will do a conceptualization of a predictive model to analyze the health effects of DEs in a society with Köppen climate classification type BW. We will do a representation of a system in order to understand how the DEs, hospital admissions, elevated PM levels, socioeconomic status (SES), and demographic factors work together. Preliminary results indicate that there are more admissions in all primary diagnoses during a DE than in a regular day.
\end{abstract}

Keywords: ecological data mining, multivariable analysis, pattern recognition, structural equation, long term health effects, oxidative stress, inflammatory responses, social economic data.

\section{Introduction}

The Southwestern region has been identified as one of the most persistent dust producing regions of North America (Orgill and Sehmel, 1976; Prospero et al., 2002). Exposure to inhalable particulate matter of 10 micrometers or less in diameter $\left(\mathrm{PM}_{10}\right)$ originating from desertic landscape during DEs can reach toxic levels (Song et al, 2007). El Paso's ambient air has reached hazardous levels of PM10 above $4000 \mu \mathrm{g} / \mathrm{m}^{3}$ with near zero visibility due to these natural events (Rivera et al., 2010), thus exceeding the primary and secondary 24-hour standard of $150 \mu \mathrm{g} / \mathrm{m}^{3}$. According to the National Ambient Air Quality Standards (NAAQS), this standard should not be exceeded more than once per year based on an average of 3 years (EPA, 2018). In El Paso, TX, DEs occur on average 14.5 times per year (Novlan, D., Hardiman, M., \& Gill, T., 2007), 
which are conditions that resemble those of the Dust Bowl during the 1930's at the Southern Plains of Texas (Lee and Gill, 2015). Deadly respiratory health problems were prevalent during that period (Alexander, Nugent and Nugent, 2018).

Recent literature has shown that exposure to desert-related particles during DEs is associated with increased hospitalizations due to respiratory or circulatory-related problems (Zhang et al. 2016). However, not much is known about the possible effects of exposure to desert-related particles during DEs on mental and neurological-related health problems. Because it has been shown that inhaled particles induce an inflammatory response that starts in the lung, spills into the circulatory system, and ultimately can reach the brain, I suspect that exposure to very high levels of particles from natural sources during DEs might increase hospitalizations due to mental and neurologicalrelated health problems. Understanding the impact of environmental exposures on these types of health problems is important as depression, Parkinson's disease and Alzheimer's disease are the three most prevalent and costly mental and neurodegenerative diseases in the U.S. (Weintraub, Karlawish \& Siderowf, 2007). Furthermore, socially disadvantaged individuals, such as those of low socio-economic status (SES) or those who are frequently exposed to discrimination and isolation (e.g., racial and ethnic minorities) tend to be more susceptible to the health effects of air pollution exposure (Grineski et al., 2015; Halonen at al., 2016). In addition, evidence suggests that factors such as age, gender, and ethnicity might affect the association between exposure to particles and health problems, but this mediating role is not clear (Howard, Peace \& Howard, 2014).

During DEs -particularly in arid regions- particles from deserted landscapes get lifted into ambient air by high wind speeds where they combine with particles emitted by urban sources (e.g., vehicles, industry source components that are in the air or settled on the roads) as well as with biological particles in nature (e.g., spores, fungi) (Fuzzi et al., 2015). Currently, there is little understanding of the health effects induced by exposure to the above-mentioned particle mixtures, which during DEs can reach high, unsafe concentrations. Exposure to DEs is more frequently experienced by populations that live in arid and semiarid regions of the world. In the United States, DEs are frequent within and around the Chihuahua Desert of Texas, which is where the proposed study will focus on. Addressing the associations between DEs and hospitalizations in these arid regions of the US will greatly inform the scientific community, habitants, and the environmental and social authorities who are responsible for implementing the proper adjustments. The following sections will provide a review of the relevant literature to and identify gaps that illustrate the significance of the proposed study.

\section{$2 \quad$ Literature Review}

\subsection{Description of the Chihuahuan Desert (EL PASO)}

This study will focus on parts of the Chihuahuan Desert (Texas) which is the most persistent dust producing regions of North America (Lee et al., 2009; Novlan et al. 2007; Rivera et al. 2009 and 2010) (see Figure 1). The high frequency of dust storms 
in these regions are due to large-scale dry climate (climate type -according to the Köppen climate classification system- cold desert (BWk), hot desert (BWh) (Lee et al., 2012; Lee and Tchakerian, 1995; Rivera et al., 2009; Bernier et al., 1998; Li et al. 2018).

The Chihuahuan Desert is the one of the most significant sources of dust in the Western Hemisphere (Prospero et al., 2002). In this region, agricultural lands, ephemeral lakes, and dry river beds have been identified as the main sources of the dust from this desert that is blown into El Paso, Texas (Lee et al., 2009). Within the Chihuahuan Desert, I will focus specifically in dust events occurring in El Paso, Texas, which is the largest city in the US that is located in the central part of the Chihuahuan Desert (see Figure 1). In El Paso, dust events have been identified as important environmental hazardous events. Based on data collected at the El Paso International Airport from 1932 through 2005, dust events in El Paso occur on average 15 times a year and last an average of 2 hours each (Novlan et al., 2007). In this region, dust storms occur most commonly during the months of December through May when ambient air is dry and winds can reach high speeds $(>25 \mathrm{mph})$ ), blowing primarily on strong westerly and southwesterly winds (Novlan et al., 2007). At wind speeds greater than $25 \mathrm{mph}$, dust can be raised into the atmosphere and/or transported for long distances by synoptic-scale weather systems (horizontal length scale of the order of 1000 kilometers or more), which results in widespread exposure to ambient air particle mixtures (Lee et al., 2009).

\subsection{Air Pollution}

Particles, also called atmospheric aerosols, that are less than $10 \mu \mathrm{m}$ in diameter $\left(\mathrm{PM}_{10}\right)$ have very low sedimentation speeds under gravity and may remain in the air for days before eventually being washed out by rain or impacted out onto vegetation or buildings, but they can be re-suspended from surfaces during a DE. These particles are a regulated environmental pollutant, being responsible for reducing visual range, soiling surfaces, and negatively impacting human health (Colls, 2002). $\mathrm{PM}_{10}$ concentrations can reach very high levels during DE, particularly in desert environments or near agricultural fields or unpaved roads where high wind speeds can lift surface particles (Jacob, et al., 2009). Ambient levels of $\mathrm{PM}_{10}$ in the US are regulated by the US Environmental Protection Agency (US EPA). Standards for $\mathrm{PM}_{10}$ consist of $150 \mu \mathrm{g} / \mathrm{m}^{3}$ during 24-hour periods and are not to be exceeded more than once per year on average over 3 years (visit https://www.epa.gov/criteria-air-pollutants/naaqs-table). Peak hourly concentration of $\mathrm{PM}_{10}$ in El Paso during a DE has reached 1,955.2 $\mu \mathrm{g} / \mathrm{m}^{3}$.

Aerosol content in the atmosphere depends on its origin (urban, rural, marine, desertic or combined), as well as physical properties and chemical composition, all of which induces different health effects within each environment (Carvalho-Oliveira, 2015). Aerosols may have either a primary or secondary origin, be solid or liquid, and come from biological or inorganic sources. Primary sources of particles include industrial processes, transport-related processes, unpaved roads, fields, fires, wood combustion, marine aerosol, and mineral dust aerosol (MDA- principal component from all the atmospheric aerosol in the planet) (Fuzzi et al., 2015). Secondary particles result from complicated reactions of chemicals in the atmosphere from compounds such as sulfur dioxides and nitrogen oxides which are typically emitted from power plants, industrial processes, and automobiles (EPA, 2018b). 
Globally, it is estimated that the main sources of particulate matter contributing to urban air pollution are: $25 \%$ by traffic, $15 \%$ by industrial activities, $20 \%$ by domestic fuel burning, $22 \%$ from unspecified sources of human origin, and $18 \%$ from natural dust and salt (Karagulian et al., 2015). However, in a dusty arid region such as in El Paso, these percentages are likely very different. At El Paso, 35\% of the total mass concentrations in the $\mathrm{PM}_{10}$ fraction accounted for Major elements from geologic sources, indicating that geologic sources in the area are the dominant PM sources through the year (Li et al., 2001).

\subsection{Characterization of Dust Storms}

Within the Southwestern US, DEs are caused by synoptic-scale Pacific cold fronts moving across the desert from west to east, and cyclones developing and intensifying to the northeast (Rivas et al., 2014). All these factors create the conditions for DEs, which is defined as an event with $\mathrm{PM}_{10}$ above $150 \mu \mathrm{g} / \mathrm{m}^{3}$ while wind speeds can have gusts above $10 \mathrm{~m} / \mathrm{s}$ (see figure 1) (Hosiokangas et al., 2004; Lee et al., 2009; Rivera et al., 2009). Low wind conditions can also lead to elevated levels of pollutants and particulates in the air. Nevertheless, per a study conducted in El Paso (Grineski et al., 2011) and one in Lubbock (Lee and Tchakerian, 1995), low wind conditions are not or rarely associated with dust events.

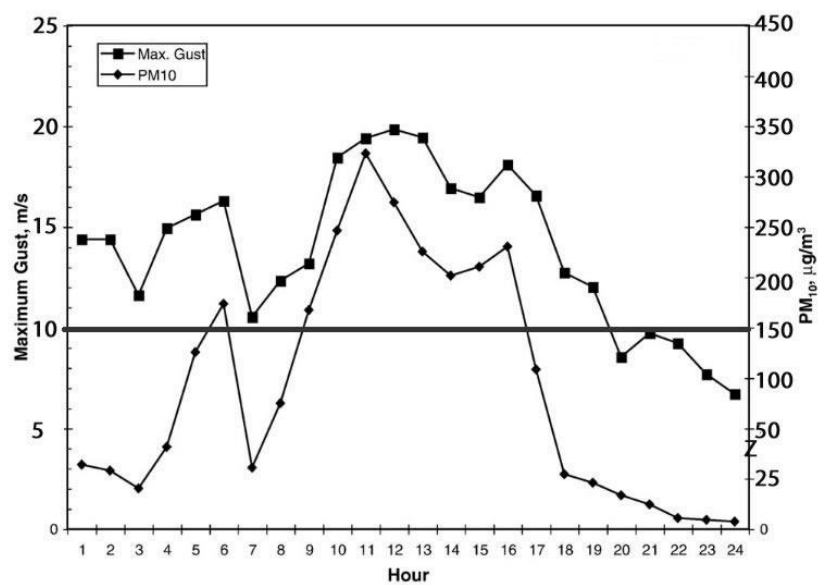

Fig. 1. Definition of a Dust Event for this study; Wind speed with gusts above $10 \mathrm{~m} / \mathrm{s}$ and $\mathrm{PM}_{10}$ above $150 \mu \mathrm{g} / \mathrm{m}^{3}$.

Desert dust can be transported across the world by arid and semi-arid regions where loose soil can easily be lifted during high wind speeds (Lim \& Chun, 2006). For instance, dust from the Sahara Desert can be transported across the Atlantic Ocean and reach northeastern South America, the Caribbean, Central America, and southeastern United States (Kanatani Et al., 2010). This transportation to distant regions by DEs is generated when strong surface winds lift up fine grained dust particles into the air and strong turbulence or convection diffuses the dust, particulate material, biological aerosols and pollutants (Shao, 2008; Zhang et al., 2016). It is estimated that $75 \%$ of the global dust emissions is due to natural origin, while $25 \%$ are related to anthropogenic 
(primarily agricultural) emissions (Ginoux et al., 2012), with the Sahara Desert as the largest source of natural mineral dust aerosol (Karanasiou et al., 2012).

It is estimated that the total dust deposition rate during a DE at El Paso, TX is approximately $195.5 \mathrm{~g} / \mathrm{m}^{2} / \mathrm{yr}$, where values are elevated in comparison to dust deposition elsewhere in the region, and closer to other global desert areas (Rivas et al., 2014). The principal size class of deposited sediment during DEs is sand $(86.81 \%)$ followed by $9.25 \%$ of $\mathrm{PM}_{10}$ and $3.94 \%$ of $\mathrm{PM}_{2.5}$. An air monitoring station near the study area at the same times indicated peak hourly $\mathrm{PM}_{10}$ values of $1955.2 \mu \mathrm{g} / \mathrm{m}^{3}$ and for $\mathrm{PM}_{2.5} 288.33$ $\mu \mathrm{g} / \mathrm{m}^{3}$ (Rivas et al., 2014).

The mineralogy of DE particles at El Paso, TX is dominated by quartz (silicon dioxide) with the presence of other common minerals such as plagioclase, gypsum, and calcite (Rivas et al., 2014). In addition to the inorganic particulate matter contained in the dust during a DE (contained in the PM), there are substantial quantities of foreign microorganisms derived from the downwind atmosphere, terrestrial, and aquatic environments (Zhang, Zhao \& Tong, 2016). Significant increases in the concentration of bacteria and fungi are commonly detected in dust clouds during sandstorm events (Tang et al. 2018). DE are known as one of the most far-reaching vehicles for transport of highly stress resistant and potentially invasive/pathogenic microorganisms across the globe (Weil et al. 2017).

\subsection{Dust, Fugitive Dust, Aerosols and their Health Effects}

In the Southern High Plains, the dominant aerosol elemental content during DE includes $\mathrm{Al}, \mathrm{Si}, \mathrm{S}, \mathrm{Cl}, \mathrm{K}, \mathrm{Ca}, \mathrm{Ti}, \mathrm{Mn}, \mathrm{Fe}$, and $\mathrm{Zn}$, with minor and trace elements $(\mathrm{Cr}, \mathrm{Ni}$, $\mathrm{Cu}, \mathrm{Rb}, \mathrm{Zr}$, and $\mathrm{Pb}$ ) (Gill, Stout and Peinado, 2009). On the other hand, Garcia et al. (2004) found that the elements in El Paso's dust-emitting soil are largely the same elements found in the Southern High Plains (Al, Ca, K, Zn, Cr, Ni, Cu, Pb and Mn), plus $\mathrm{Na}, \mathrm{Ag}, \mathrm{As}, \mathrm{Cd}, \mathrm{Mo}, \mathrm{Sb}, \mathrm{Ba}, \mathrm{Co}$, and Be (Li et al., 2001), which are fugitive dust sources that might increase during dust events. A recent study near Las Vegas, NV during a DE showed that accumulated particles on the road are re-suspended. These suspended particles are composed of a more complex mixture of elements, including $\mathrm{Al}, \mathrm{V}, \mathrm{Cr}, \mathrm{Mn}$, $\mathrm{Fe}, \mathrm{Co}, \mathrm{Cu}, \mathrm{Zn}, \mathrm{As}, \mathrm{Sr}, \mathrm{Cs}, \mathrm{Pb}, \mathrm{U}$, and others (Keil et al., 2016), This fugitive dust are disease precursor with hazardous effects on human health (e.g. carcinogenic and noncarcinogenic) (Khan, \& Strand, 2018; Kioumourtzoglou et al., 2015). Furthermore, Huang et al. (2014) found house air-conditioner dust to be more hazardous than road dust; within these particles lead was the most abundant element, followed by arsenic.

Several studies have hinted that exposure to particle air pollution during dust events could have a direct impact on human health (Anderson et al., 2013). This is because the $\mathrm{PM}<10 \mu \mathrm{m}$ can penetrate into the lungs and exposures are based upon respirable dust $(\leq 5 \mu \mathrm{m})$ (Bhagia, 2012; Middleton, 2017). For example, the size fractions of silica in ambient dust is in the range of $2.5-15 \mu \mathrm{m}$ and $\mathrm{PM}<2.5 \mu \mathrm{m}$ can penetrate into deep lung tissue (Bhagia, 2012). Besides the composition of particles, and the size and surface area of breathable particles, air pollution has been found to affect the degree of oxidative stress and the release of cytokines, accelerating inflammation in the body (Dostert et al., 2008; Ghio et al., 2004) (see Figure 2). Systemic inflammation, endothelial activation, and low-grade inflammation caused by inhaled traffic-related PM ( $\mathrm{Li}$ et al., 
2015; Chiarelli et al., 2011), has been hypothesized as a key factor in the pathway leading to detrimental structural and cognitive effects, as well as neurodegenerative and mental illnesses (Calderón-Garcidueñas et al., 2015; Heusinkveld et al., 2016).

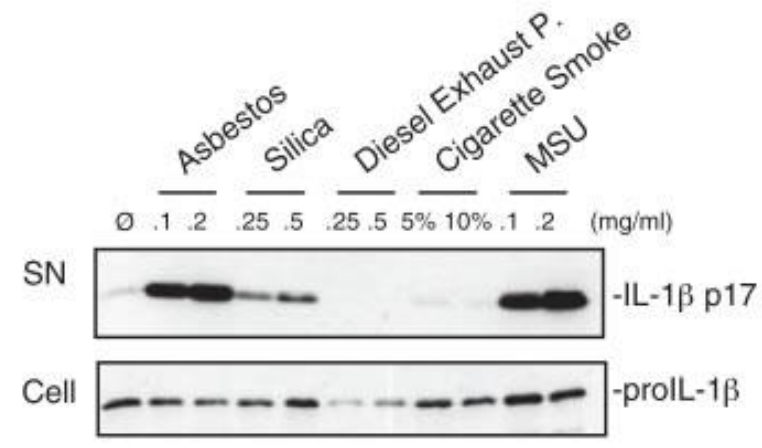

Fig. 2. Silica activate IL-1B secretion in human macrophages. Analyzed in media supernatants (SN) and in cell extracts (Cell). From Dostert et al. 2008.

In addition, recent studies have shown that particle air pollution during DE increase hospitalizations for expected causes such as respiratory and cardiovascular disorders (Khaniabadi et al., 2017; Yu, Chien, and Yang, 2012). Even more, recent studies suggest that silica dust influence brain function and aggravates spinal cord injury. Exposure to silica dust increases epithelial permeability in patients with silicosis who smoke (Nery et al., 1993). Keil et al. (2018) performed an exposure study to dust at the southwest USA with a PM median diameter of 4.6, 3.1, and $4.4 \mu \mathrm{m}$. Results showed an overall reduction in the immune response rather than a direct effect of dust samples on neuronal protein-specific antibody production but neurotoxicity cannot be ruled out as a concern. Also, increased levels of serum creatinine -a marker for kidney functionwere found. A previous study (Keil et al., 2016) showed that brain CD3+ T cells were decreased in number after dust exposure with silica and heavy metals present in the southwest soil.

Hospitalizations after a DE have been reported to have a prolonged effect on the day of the DE and on the week after the DE (Chien, Yang and Yu et al., 2012). Therefore, in this study, hospitalizations will be under particular scrutiny during those day(s) when a dust storm event is taking place, as well as all throughout the following week.

\subsection{Biological Aerosol Particles and its Health Effects}

Sandstorms from the Sahara Deserts transmit roughly a billion tons of dust across the atmosphere, and the region is considered one of the major sources of the intercontinental dust transport (Griffin 2007). The Gobi and Taklamakan Deserts in Asia are the second largest sources (Zhang et al., 2016). These dust plumes can reach as far as the Americas (Husar et al., 2001), transporting trillions upon trillions of microbes into the air and downwind destinations along their intermediate path which are added to the own desert microbiome (Behzad, Mineta \& Golobori, 2018). By some estimate, a cubic meter of air contains hundreds of thousands of microorganisms (Prussin et al., 2015; Brodie et al., 2007), with an extensive diversity of taxa (Franzetti et al., 2011). 
Mineral dust aerosol (MDA) contains primary biological aerosol particles (PBAPs) and has a large range of different biological components, including microorganisms (bacteria, archaea, algae and fungi) and dispersal material (pollen, fungal spores, viruses and biological fragments) (Fuzzi et al., 2015). Furthermore, large deserts create their own Dust Storm Derived Microbiota (DSM) (Griffin, 2007). This microbiota includes highly stress-resistant microorganisms (bacteria and fungi) that are capable of thriving in harsh environmental conditions with restricted water and nutrient availability, extreme temperatures, and UV irradiation (Chan et al. 2013; Etemadifar et al., 2016). Viruses on the other hand can undergo degradation by atmospheric processes and can experience a possible loss of their toxic effects in the source regions as they are carried away (Despres et al., 2012). This large-scale transmission of highly resistant microbial contaminants raises concerns with regards to human health (Chung and Sobsey, 1993 and Cox, 1995).

It has been proven that viruses present during $\mathrm{DE}$ are taxonomically diverse (Zablocki et al., 2016) and are transported by the dust across long distances (Chien et al., 2012; Chung and Sobsey, 1993). This movement leads to significantly higher cases of Influenza A virus, typhus, cholera, malaria, dengue and West Nile virus infection than is typically observed during normal non-DE days (Griffin, 2007). Examples of influenza outbreaks type A virus and H5N1 avian influenza occurred in Taiwan, Japan and South Korea during the Asian Dust Storms (ADS) that originated in the deserts of Mongolia and China (Chen et al. 2010).

Bacterial epidemics are strongly linked to DEs. Bacterial meningitis is associated with DEs, which is a major predictor of the timing of meningitis epidemics (Agier et al., 2013). In 1935, Kansas experienced a severe measles epidemic during the Dust Bowl. Hospital admissions were largely for acute respiratory infections such as pneumonia, sinusitis, laryngitis and bronchitis (Brown et al., 1935). Similar cases of respiratory infections due to DE can be found in Western China (Ma et al., 2017). The epidemics of pulmonary tuberculosis was similarly linked to ADS in China (Wang et al., 2016). ADS were also positively associated with diabetes in women (Chan et al., 2018).

Another infectious disease presumably caused by fungi during a DE is the Valley Fever, whose fungal causative agents (Coccidioides immitis and Coccidioides posadasii) are primarily found in hot and arid desert soil (Kirkland and Fierer, 1996). The outbreaks of Kawasaki disease (a serious heart complication acquired in childhood) was linked to a fungal Candida species found in DE from China (Rodo et al. 2014; Tong et al. 2017).

\subsection{Inflammatory Response Pathway}

The inflammatory response helps the body fight and clear infection, remove damaging chemicals, and repair damaged tissue. However, frustrated phagocytosis (an action where a phagocyte fails to engulf its target and toxic agents can be released) can have a harmful effect on the body (Dostert et al., 2008). At its worst, inflammation can provoke cancer (Tili et al., 2011). There are two pathways that link PM air pollution (gases, ultrafine particles, and nanoparticles present in the particulate matter like silica from the dust) to adverse health outcomes (Shrey et al., 2011). 
The first is a direct pathway, which consists of the local oxidative stress/inflammation effects of pollutants on the cardiovascular system, blood, and lung receptors (Garcia et al., 2015). This direct pathway involves the direct translocation (the dominant method of trapping and processing particles in the lung tissue) of inhaled fine particles present in the PM into the circulatory system causing intracellular oxidative stress releasing cytokines and chemokines (Nemmar et al., 2010). Particles can readily cross the pulmonary epithelium or the lung-blood barrier due to their particle size, charge, chemical composition, and propensity to form aggregates (Oberdörster et al., 2004). Once such particles like silica are in circulation, they lead to further deleterious effects such as local oxidative stress and inflammation (Brook et al., 2010). The mechanism starts with local inflammation in the upper and lower respiratory tract resulting in increased levels of pro-inflammatory mediators (e.g., IL-6, IL-8, and of tumor necrosis factor alpha (TNF- $\alpha$ ) following into the circulatory system inducing low-grade peripheral inflammation (see Figure 3) (Olvera et al., 2018). An example of this direct pathway is that in rats, a three-hour PM2.5 exposure has been shown to lead to a rapid increase of reactive oxygen species (ROS) generation in the heart and lungs (Gurgueira et al., 2002; Li et la., 2015).

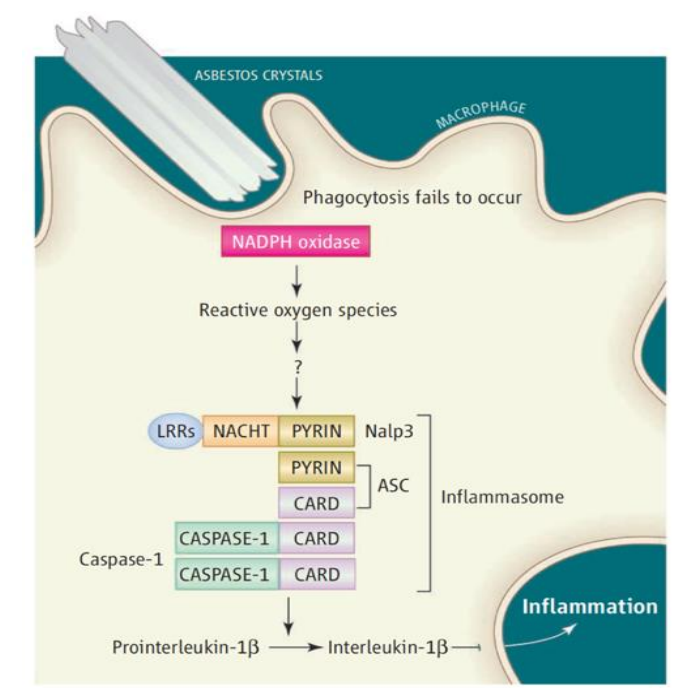

Fig. 3. Systemic inflammation mechanism due to DE. Asbestos crystals or silica are too large to be phagocytosed by macrophages and so are subject to "frustrated" phagocytosis. This leads to activation of NADPH oxidase and the generation of reactive oxygen species. This event activates the Nalp3 and ASC inflammasome promoting the processing and release of the potent proinflammatory molecule interleukin-1B. From O'Neill et al., 2008.

The second pathway is the classical pathway, which explains the indirect effects mediated through pulmonary oxidative stress and inflammatory responses (Nemmar et al., 2003; Tonne et al., 2016). It begins when inhaled traffic-related PM enters the body through the airway to the lungs and causes a local inflammatory response at the bronchial epithelial cells and from alveolar macrophages (Bai and Sun, 2015). Bronchial 
epithelial cells and alveolar macrophages are in prolonged contact with the inhaled particulates when clearing them from the lung, which can initiate and sustain inflammatory responses (Dostert et al., 2008). Silica are sensed by the Nalp3 inflammasome, whose subsequent activation leads to interleukin- $1 \mathrm{~b}$ secretion. The onset of this inflammatory response, at a cellular level, is triggered by the release of TNF- $\alpha$ and IL- $1 \beta$ which regulate the expression of various secondary cytokines and chemokines, including IL-6 and IL-8 (Schwarze et al., 2013; Morman and Plumlee, 2013).

\subsection{Health Disparities}

Health disparities are health differences that adversely affect socially disadvantaged groups (Krieger, 2016). Health disparities are systematic, reasonably avoidable health differences according to race/ethnicity, skin color, religion, or nationality; socioeconomic resources or position (reflected by, e.g., income, wealth, education level, or occupation); gender, sexual orientation, gender identity; age, geography, disability, illness, political or other affiliation; or other characteristics associated with discrimination or marginalization. These categories reflect social advantages or disadvantages when they determine an individual's or group's position in a social hierarchy (Braveman et al., 2011). Furthermore, inequities in social determinants of health, including neighborhood poverty, crime rates, and reduced access to high-earning jobs, housing, transportation, and healthy foods significantly contribute to these disparities (Cooper et al., 2016). Disparities in health and its determinants are the metric for assessing health equity (Gee, Walsemann, \& Brondolo, 2012). An example of health disparities is that being overweight is negatively associated with income, education level, and occupation at the municipality level (Kinge et al., 2016).

Moreover, social factors (e.g., stress, health disparities, low access to resources) may induce intrinsic vulnerability to the effects of air pollution, including a pro-inflammatory phenotype that results in increased inflammatory reactivity to air pollution exposure that may be heritable (Wu et al., 2016; Heusinkveld et al., 2016). An example of this is the impact of PM2.5 on markers of systemic inflammation and oxidation in those with multiple pre-existing cardiovascular diseases with elements of metabolic syndrome (e.g. obesity, diabetes, hypertension and smokers) (Aguilar et al., 2015).

Opposite to health disparities, gender, age and genetics are a natural disorder cause. For example, a study by Reynolds et al. (2016) found that women experienced a significantly greater decrease in incidence of myocardial infarctions compared with men. Other investigators suggest that cumulative stress may result in affecting biological processes, such as shortening telomere length. The length of telomeres on chromosomes declines with age and may be an indicator of remaining life expectancy. Some evidence suggests that there is a systematic relationship between educational attainment and the length of telomeres (Adler et al., 2013; Kaplan, 2014).

\subsection{Dust Storm Projections}

For the last 50 years, an acceleration of changes on the average climate conditions (IPCC, 2007a) has been observed. The average global temperature has increased by $0.7^{\circ} \mathrm{C}$ and it is expected to increase between 1.8 and $4.0^{\circ} \mathrm{C}$ by the year 2100 (IPCC, 2007b; Hansen et al., 2006). The frequency of dust storms has increased during the last 
decade and forecasts suggest that this will continue to rise in response to anthropogenic activities and climate change (Schweitzer et al., 2018). El Paso del Norte is the region that has the highest probability for DE (Rivera, Rivera et al., 2009).

Climate change poses unprecedented threats to human by impacts on health, food and water security, heat waves and droughts, dust storms, and infectious diseases; whether or not humanity will successfully adapt is not yet known (Barrett et al., 2015). Some infectious diseases and their animal vectors are influenced by climate changes, resulting in higher risk of typhus, cholera, malaria, dengue and West Nile virus infection which are carried by DE (Franchini \& Mannucci, 2015). Moreover, climate drivers (increase of temperatures, changes in precipitations patters, extreme weather effects), environmental changes (changes in pollutant exposure, changes in allergens production, timing and distribution), urban landscapes, emission patters), and social and behavioral context (income, education, sensitivity, adaptive capacity and housing quality) can affect an individual's or a community's health vulnerability over the time (Global Change, 2017).

\section{Methodology}

\subsection{Data Sources}

Hospital admissions: Five years of data were obtained from the Texas Hospital Inpatient Research Data files (RDF) from the Texas Department of State Health Services (TDSHS) for years 2010 through 2014 for El Paso TX. The data included the following five variables: the date of admission, census block group of the patient, the patient's age, gender, ethnicity, and the principal diagnostic code from the International Classification of Diseases, Ninth Revision (ICD)-9 (see Table 1). The principal diagnostic code was preferred over other diagnostic codes because it better captures the exacerbations of disease as opposed to other diagnostics due to existing diseases.

PM and wind speed data: Hourly averages of $\mathrm{PM}_{10}$ concentrations, wind speed (m/s), relative humidity, and mean, minimum, and maximum temperature $(\circ \mathrm{F})$ measured at Continuous Air Monitoring Stations (CAMS) located in El Paso, Lubbock, Midland and Amarillo, listed in Table 1, from 2010-2014 will be downloaded from the Texas Commission on Environmental Quality (TCEQ) website. $\mathrm{PM}_{10}$ and wind speed missing data will be interpolated using a temporal linear method in cases where the data were missing for three consecutive hours or less; days with data missing for four or more consecutive hours will be excluded from the analysis. It is expected that of the total dataset, about $1 \%$ of all analyzed days would require missing data interpolation; after interpolation, the dataset will be over $99.7 \%$ complete.

Socio-economic data: Economic characteristics, including income, level median income, poverty, occupation and education for each patient address census block group will be obtained from the U.S. Census Bureau's American Community Survey for the 2010-2014 period. It will help us to identify susceptible individuals. This information will be connected with the RDF's Address Census Block Group code of each hospitalized patient in the CDT and HPWT. 
Demographic data: Population increase or decrease (in millions) data between 20102014 will be obtained from the census data of statistics in the county of El Paso, Texas, to remove these non-environmental confounding elements (population increase or decrease).

Table 1 Codes from the International Classification of Diseases, Ninth Revision (ICD)-9.

\begin{tabular}{|c|c|c|c|}
\hline Code Range & Diagnosis & Code Range & Diagnosis \\
\hline $1001-139$ & $\begin{array}{l}\text { Infectious and parasitic dis- } \\
\text { eases }\end{array}$ & $10580-629$ & $\begin{array}{l}\text { Diseases of the genitouri- } \\
\text { nary system }\end{array}$ \\
\hline $2140-239$ & Neoplasms & $11630-679$ & $\begin{array}{l}\text { Complications of preg- } \\
\text { nancy, childbirth, and the } \\
\text { puerperium }\end{array}$ \\
\hline $3240-279$ & $\begin{array}{l}\text { Endocrine, nutritional and } \\
\text { metabolic diseases, and im- } \\
\text { munity disorders }\end{array}$ & $12680-709$ & $\begin{array}{l}\text { Diseases of the skin and } \\
\text { subcutaneous tissue }\end{array}$ \\
\hline $4280-289$ & $\begin{array}{l}\text { Diseases of the blood and } \\
\text { blood-forming organs }\end{array}$ & $13710-739$ & $\begin{array}{l}\text { Diseases of the musculo- } \\
\text { skeletal system and con- } \\
\text { nective tissue }\end{array}$ \\
\hline $5290-319$ & Mental disorders & $14740-759$ & Congenital anomalies \\
\hline $6320-389$ & $\begin{array}{l}\text { Diseases of the nervous sys- } \\
\text { tem and sense organs }\end{array}$ & $15760-779$ & $\begin{array}{l}\text { Certain conditions origi- } \\
\text { nating in the perinatal pe- } \\
\text { riod }\end{array}$ \\
\hline $7390-459$ & $\begin{array}{l}\text { Diseases of the circulatory } \\
\text { system }\end{array}$ & $16780-799$ & $\begin{array}{l}\text { Symptoms, signs, and ill- } \\
\text { defined conditions }\end{array}$ \\
\hline $8460-519$ & $\begin{array}{l}\text { Diseases of the respiratory } \\
\text { system }\end{array}$ & $17800-999$ & Injury and poisoning \\
\hline $9520-579$ & $\begin{array}{l}\text { Diseases of the digestive } \\
\text { system }\end{array}$ & 18 E000-E999 & $\begin{array}{l}\text { Supplementary classifi- } \\
\text { cation of external causes } \\
\text { of injury and poisoning }\end{array}$ \\
\hline
\end{tabular}

\subsection{Model Analyses}

Dust storm periods will be identified by matching the hourly average $\mathrm{PM}_{10}$ exceeding $150 \mu \mathrm{g} / \mathrm{m}^{3}$ and high winds above $10 \mathrm{~m} / \mathrm{s}$ (Rivera et al., 2009). In order to estimate the influence of dust storm's particulate matter from hospitalizations, a regression model will be generated to determine the correlations between the identified dust storms and hospitalizations during one-week period (the day of the storm and week after the dust storm) identified in El Paso county.

SES data from the U.S. Census Bureau's American Community Survey for the 20102014 period will be connected with the RDF's Address Census Block Group code of each hospitalized patient identified. An association between diseases outcomes and SES, (including income, poverty level, occupation and education level at county level in El Paso, TX) will be looked upon. Also, it will be searched if there is a remarkable reduction/increase in the incidence of hospitalized residents with any disease that is affected by dust events from 2010-2014. A search will be conducted for an association 
between diseases and SES, including age, sex, and race at county level county level in El Paso, TX.

Model analysis will be applied using data mining. A conceptual model will be applied to establish a basic model to explore the associations between the predictor variable (Dust events) and response variables (admissions, age, sex and SES). I will remove long-term trends and seasonal patterns from the data to protect against confounding by omitted variables. I will control for season and long-term trend with a natural cubic regression spline with 1.5 degrees of freedom (df) for each season and year (corresponding to $6 \mathrm{df}$ per year). In addition, I will include natural splines with three df for temperature on the day of the admission and with $2 \mathrm{df}$ for the six following days and a linear term for daily average humidity and dummy variables for the day of the week effect and public holidays. Once the data is normalized, each diagnosis code will be categorized into; acute, chronic and mental, in order to have a better understanding of the associations between DEs and diagnosis. Separated models will be run for each outcome of significant primary diagnosis. Models for present (2010-2014) and future projections (2020 and 2050) will be modeled separately.

In addition, geographic maps will be created in each municipality indicating their $\mathrm{PM}_{10}$ levels and hospital admissions percentage during a DE and their association between each socio-economic factor per 1000 population in El Paso, TX between 2010 and 2014 and projected outcomes (2020 and 2050). This will be done by using the Empirical Bayesian Kriging (EBK) Regression Prediction Method by ArcGIS (ESRI, Redlands, CA, USA).

\section{$4 \quad$ Preliminary Results}

We propose that projected health outcomes due to DEs are manifested by patient hospitalization which is associated with environment, demographic and socio-economic factors as the following model and formulas indicate (Figure 4).

$$
\alpha=\mathrm{i}(\gamma+\delta+\varepsilon+1) \pm i d,
$$

where Educational attainment $(\alpha)$ is defined by: $\gamma=$ Neighborhood, $\delta=$ Access to education, $\varepsilon=$ Parent expectations about children, $\mathrm{l}=$ Local inequities/disparities (these factors are rated from 1 to 10 , being 1 the lowest given value and 10 the highest according the present and projected ratings for 2020 and 2050 in each Census Block Group code at the El Paso County) and $l=$ Income (value given from the Census Block Group code at the El Paso County and projected values for 2020 and 2050).

$$
\mathrm{Z}=(\zeta)^{\mathrm{gi}}
$$

where Occupation (Z) is defined by: $\zeta=$ Occupation (value given from the Census Block Group code at the El Paso County) and gi= Inequities/disparities based on globalization (rated from 0 to 10 , being 1 the lowest given value and 10 the highest according the present and projected ratings in each Census Block Group code at the El Paso County). 


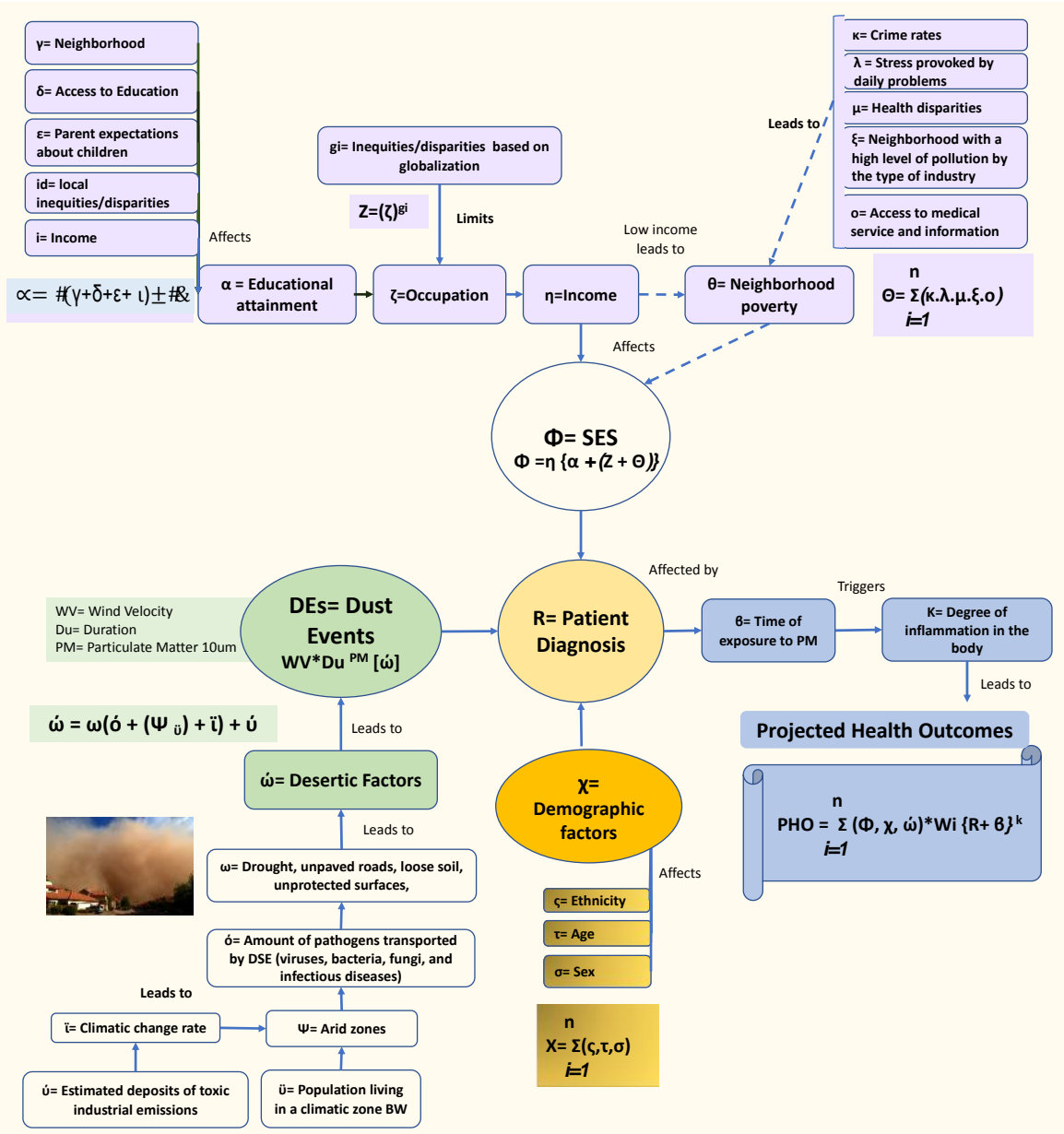

Fig. 1. Conceptual predictive model of DEs and its health outcomes in a society of BW climate.

$$
\underset{\substack{\mathrm{n} \\ i=1}}{\mathrm{n}}(\kappa . \lambda . \mu . \xi . \text { о. }),
$$

where Neighborhood poverty $(\theta)$ is defined by: $\kappa=$ crime rates, $\lambda=$ stress provoked by discrimination, $\mu=$ health disparities, $\xi=$ Neighborhood with a certain level of pollution according to the type of industry and $\mathrm{o}=$ access to medical service and information.

$$
\Phi=\eta\{\alpha+(Z+\Theta)\}
$$

where SES $(\Phi)$ is defined by: $\eta=$ income, $\alpha=$ Educational attainment, $Z=$ Occupation, $\theta=$ Neighborhood poverty. 
where Demographic Factors $(\chi)$ is defined by: $\varsigma=$ Ethnicity, $\tau=$ Age and $\sigma=$ Sex.

$$
\hat{\omega}=\omega\left(o^{\prime}+\left(\Psi_{\ddot{v}}\right)+\ddot{i}\right)+\dot{v}
$$

where Desertic factors ( $\dot{\omega})$ is defined by: ó= Amount of pathogens transported by DSE (viruses, bacteria, fungi, and infectious diseases), $\Psi=$ Arid Zones, $\ddot{v}=$ Population living in a climatic zone BW, $\ddot{\imath}=$ Climatic Change, $\omega=$ Drought, unpaved roads, loose soil, unprotected surfaces and $v=$ Estimated deposits of toxic industrial emissions.

$$
\mathrm{DEs}=\mathrm{WV} * \mathrm{Du}{ }^{\mathrm{PM}}[\hat{\omega}],
$$

where Dust events (DEs) is defined by: $\mathrm{WV}=$ Wind Velocity, $\mathrm{Du}=$ Duration, $\mathrm{PM}_{10}=$ Particulate Matter and $\omega=$ desertic factors.

$$
\mathrm{PHO}=\underset{i=1,}{\mathrm{n}}(\Phi, \chi, \dot{\omega})^{*} \mathrm{Wi}\{\mathrm{R}+6\}^{\mathrm{k}}
$$

where Projected Health Outcomes for $2030-2050$ (PHO) is defined by: $\Phi=$ SES, $\chi=$ demographic factors, $\dot{\omega}=\mathrm{DEs}, \mathrm{R}=$ Patient hospitalization, $b=$ Exposure time to PM10 and $\mathrm{K}=$ Degree of inflammation in the body. In this equation, PHO refers to the Projected Health Outcomes ether for the present (2010-2014), or projections for 2030 and 2050 due to DEs: denotes the sum of $\Phi=$ SES, $\chi=$ Congenital factors and $\omega=$ DSE; which affect the $\mathrm{R}=$ Patient hospitalization due to; $b=$ Exposure time to $\mathrm{PM}$; and may be exacerbated by $\vartheta=$ risk of detrimental structural and cognitive effects, neurodegenerative as well as mental illnesses. Now we have a predictive model to analyze the health outcomes of dust events in a society with Köppen climate classification type BW.

Preliminary results of the investigation have find a preponderant value between the relationship between the location of patients in the metropolitan area of El Paso, TX and the correlation present between the age of patients and their income, which will allow explain how susceptible people are poorer and affected due to possible malfunction of their own houses and susceptibility, which may be not prepared for continuous events associated with DSE, which continuously affect patients (see Figure 11). A primary aspect of our developed model, is that it can adequately estimate the prevalence of a disease or group of diseases associated with a DSE considering its duration and frequency.

Spearman's correlations indicate that dust events (events with high PM10 and wind speed values) are significant associated to diagnosis with a $\mathrm{p}$ value of 0.008 . Figure 5 shows that from 2010-2014 there were more hospitalizations in a DE (62\%) than in a 
regular day (RD) (38\%). Figure 6 shows that during DE there were 0.4 more hospitalizations due to acute conditions; 0.4 more from chronic conditions and 0.5 more from mental health than in a regular day from 2010-2014. Figure 7 shows the increase in hospitalizations during 8 days after a DE and emphasized the possible effect of PM exposure during these events and hospitalizations; the effect of a DE on hospitalizations might be highest during the actual day of the DE and such effect decreases after that.

Table 1. Comparison of ICD-9 diagnosis in a regular day and in a DE from 2010-2014.

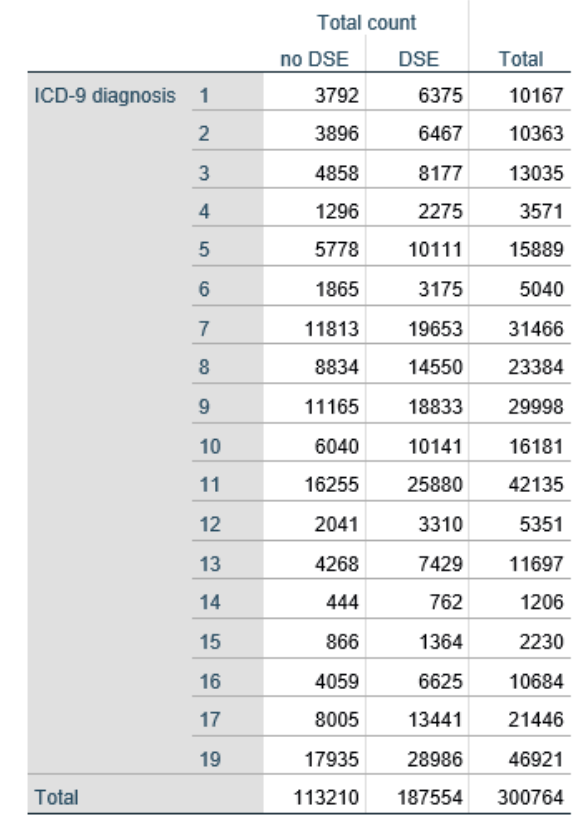

The top 7 causes of admission during a DE from 2010-2014 are: causes of injury \& poisoning $(15.6 \%)$, complications of pregnancy, childbirth, \& the puerperium $(14 \%)$, diseases of the circulatory system (10.5\%), diseases of the digestive system (10\%), and diseases of the respiratory system $(7.8 \%)$, diseases of the genitourinary system $(5.4 \%)$ and mental disorders (5.3\%) (Table 3 and Figure 8 ).

Table 4 shows the top high-risk reasons for hospitalizations, aside from deliveries, respiratory (pneumonia, obstructive chronic bronchitis, asthma) mental (unspecified episodic mood disorder, cerebral artery occlusion, unspecified with cerebral infarction, schizo-affective type schizophrenia unspecified state); cardiovascular (other chest pain, coronary atherosclerosis of native coronary artery, atrial fibrillation); and infectious (urinary tract infection, acute pancreatitis, acute appendicitis without mention of peritonitis) which are affected by bacteria, virus, or due to inflammation.

More patients live in areas with more roads and DE shows to affect the population with all incomes but more frequent patients with a family income of $<40,000$ dollars; and there are more cases of single born in areas with low income at El Paso, TX from 2010-2014 (Figure 10). There are 59.5 more females hospitalized than males $(40.5 \%)$ during 2010-2014 at El Paso County (Figure 9). 
Estrella Molina-Herrera, Alberto Ochoa, Thomas Gill, Gabriel Ibarra-Mejia, Carlos Herrera

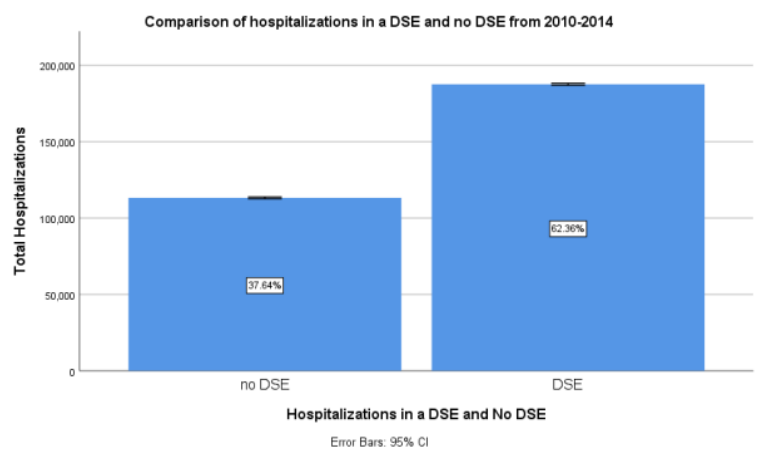

Fig. 2. Comparison of total hospitalizations in regular Days and DE from 2010-2014. There were more hospitalizations in a DE (62\%) than in a regular day (RD) $(38 \%)$.

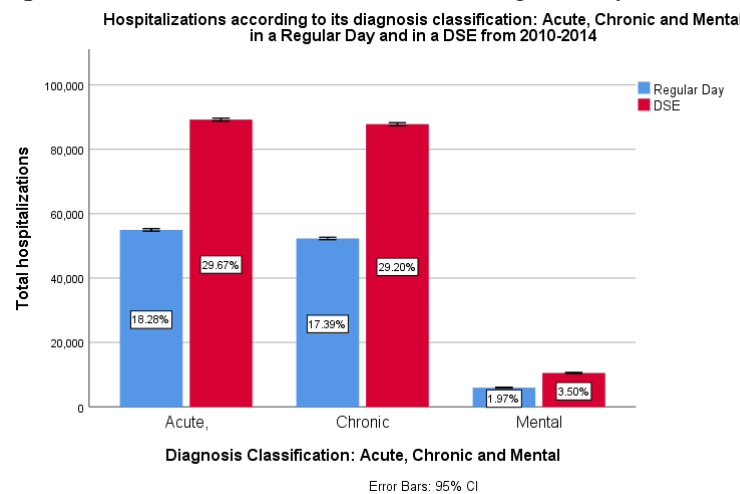

Fig. 3. Comparison of Acute, Chronic and Mental total Admissions code in a DE vs a regular day. During DEs there were 0.4 more hospitalizations due to acute conditions; 0.4 more from chronic conditions and 0.5 more from mental health than in a regular day from 2010-2014.

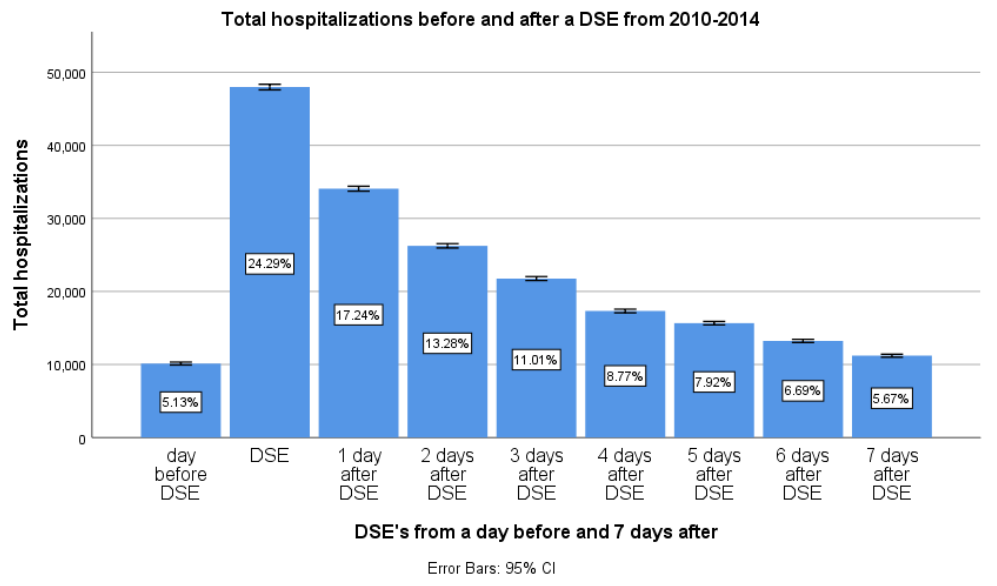

Fig. 4. Total Hospitalization percentage per day before and after DE (each day has many hospitalizations) from 2010-2014. There is an increase in hospitalizations after a DE and emphasized the possible effect of $\mathrm{PM}_{10}$ exposure during these events and hospitalizations; the effect of a DE on hospitalizations might be highest during the actual day of the DE and such effect decreases after that. 


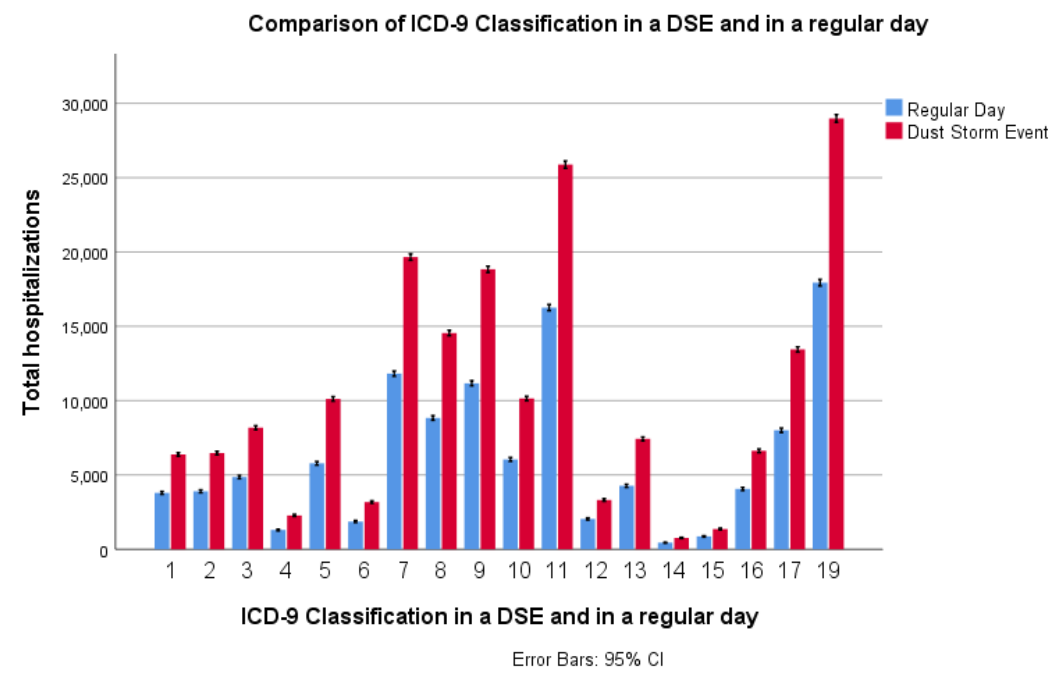

Fig. 5. Comparison of total IDC-9 Admissions code in a DE vs a regular day from 2010-2014. The top 7 causes of admission during a DE from 2010-2014 are: causes of injury \& poisoning (15.6\%), complications of pregnancy, childbirth, \& the puerperium (14\%), diseases of the circulatory system $(10.5 \%)$, diseases of the digestive system (10\%), and diseases of the respiratory system $(7.8 \%)$, diseases of the genitourinary system $(5.4 \%)$ and mental disorders $(5.3 \%)$.

Table 2. List of most frequent ICD-9 diagnosis during DEs due to high-risk Respiratory, Mental, Cardiovascular and Infection causes from 2010-2014.

\begin{tabular}{|c|c|c|}
\hline & Top reasons for hospitalizations & ICD-9 \\
\hline \multirow{3}{*}{ Respiratory } & Pneumonia, organism unspecified & 486 \\
\hline & $\begin{array}{l}\text { Obstructive chronic bronchitis with (acute) ex- } \\
\text { acerbation }\end{array}$ & 491.21 \\
\hline & $\begin{array}{l}\text { Asthma, unspecified type, with (acute) exacer- } \\
\text { bation }\end{array}$ & 493.92 \\
\hline \multirow[t]{3}{*}{ Mental } & Unspecified episodic mood disorder & 296.90 \\
\hline & $\begin{array}{l}\text { Cerebral artery occlusion, unspecified with } \\
\text { cerebral infarction }\end{array}$ & 434.91 \\
\hline & $\begin{array}{l}\text { Schizo-affective type schizophrenia unspeci- } \\
\text { fied state }\end{array}$ & 295.90 \\
\hline \multirow[t]{3}{*}{ Cardiovascular } & Other chest pain & 786.59 \\
\hline & $\begin{array}{l}\text { Coronary atherosclerosis of native coronary ar- } \\
\text { tery }\end{array}$ & 414.01 \\
\hline & Atrial fibrillation & 427.31 \\
\hline \multirow{3}{*}{ Infection } & Urinary tract infection, site not specified & 599.0 \\
\hline & Acute pancreatitis & 577.0 \\
\hline & $\begin{array}{l}\text { Acute appendicitis without mention of perito- } \\
\text { nitis }\end{array}$ & 540.9 \\
\hline
\end{tabular}


Comparison of hospitalizations according to patient sex during a regular day and in a DSE from 2010-2014

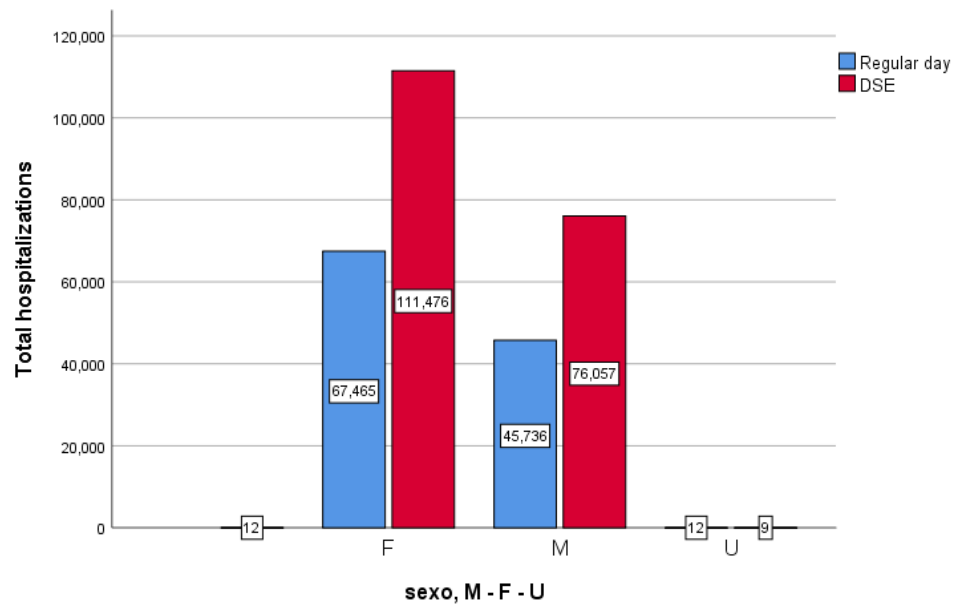

Fig. 9. Comparison of total hospitalizations by Female, Male and Unknown in a RD and in a DE from 2010-2014. There are 59.5 more females hospitalized than males (40.5\%) during 2010-2014 at El Paso County.

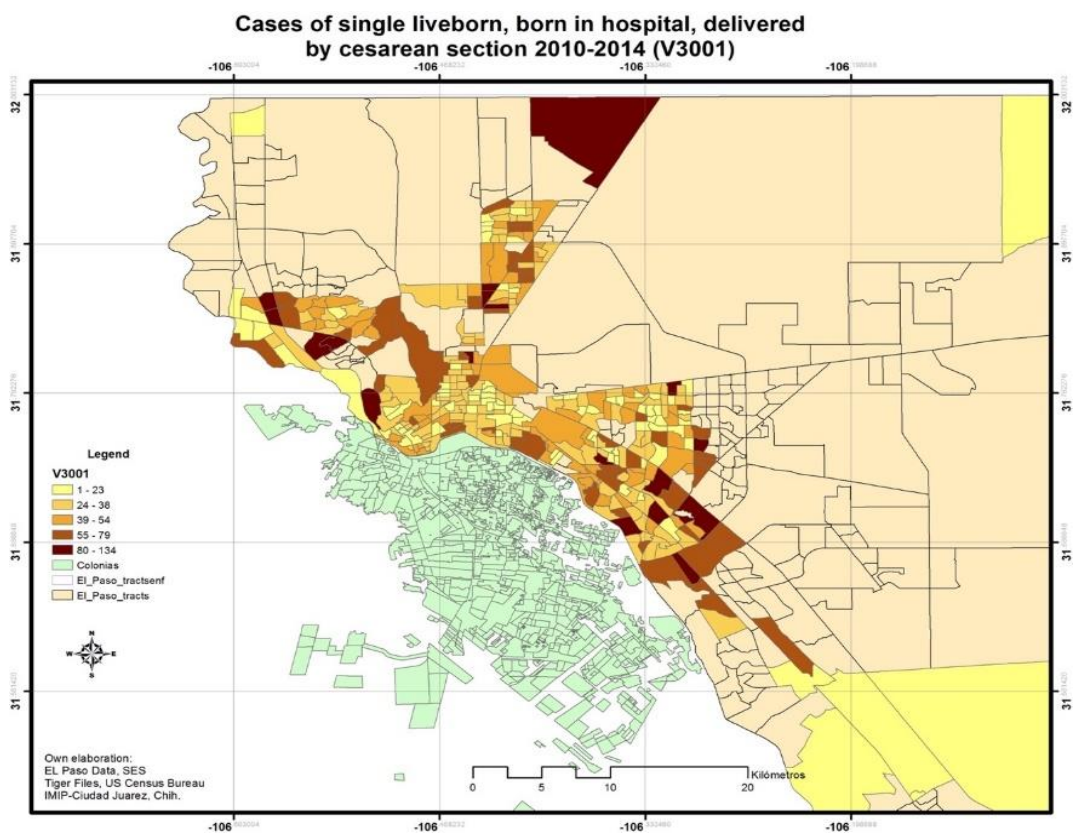

Fig. 10. Map of cases of single born by cesarean section during DEs at El Paso, TX from 2010-2014. More patients live in areas with heavily trafficked roads and DE shows to affect the population with all incomes but more frequent patients with a family income of $<40,000$ dollars; and there are more cases of single born in areas with low income at El Paso, TX from 2010-2014. 


\section{$5 \quad$ Conclusions and Future Work}

Several studies have tried to explain the most relevant aspects of the adverse outcomes of DEs in climates type BW, however none had proposed a reliable model associated with the numerical prediction of the present and projected impacts for 2020 and 2050. This research discusses a multifactorial problem, which requires a multivariate analysis which will be elaborated in the following research phase. In addition, we will Investigate whether dust exposure to $\mathrm{PM}_{10}$ during a DE (day of and 7 days after) between 2010 and 2014 is associated with hospital admissions due to acute or accelerated disease progression of neurodegenerative diseases (Parkinson's, Alzheimer's, and Huntington's), mental illness (depression and anxiety) and OD (e.g. respiratory, cardiovascular, infectious diseases and top diagnosis significantly associated by DE -diagnosis listed in the ICD9) in El Paso, TX. In addition, we will look into the biological plausibility of these diseases in order to establish a cause-and-effect relationship between $\mathrm{PM}_{10}$ during a DE and each significantly associated disease.

Note *: The contents do not represent the views of the U.S. Department of Veterans Affairs or the United States Government.

\section{References}

1. Adler, N., Pantell, M.S., O'Donovan, A.: Educational attainment and late life telomere length in the Health, Aging and Body Composition Study. Brain Behav. Immun. 27, 15-21 (2013)

2. Agier, L., Deroubaix, A., Martiny, N., Yaka, P., Djibo, A., Broutin, H.: Seasonality of meningitis in Africa and climate forcing: Aerosols stand out. Journal of the Royal Society Interface, 10(79) (2013)

3. Aguilar, M., Bhuket, T., Torres, S., Liu, B., Wong, R.J.: Prevalence of the metabolic syndrome in the United States, 2003-2012. JAMA: J. Am. Med. Assoc. 313, 1973-1974 (2015)

4. Al, B., Bogan, M., Zengin, S., Sabak, M., Kul, S., Oktay, M. M., ... Vuruskan, E.: Effects of Dust Storms and Climatological Factors on Mortality and Morbidity of Cardiovascular Diseases Admitted to ED. Emergency Medicine International, 2018(Dm), 1-7 (2018).http://doi.org/10.1155/2018/3758506

5. Alexander, R., Nugent, C., Nugent, K.: The Dust Bowl in the US: An Analysis Based on Current Environmental and Clinical Studies. The American Journal of the Medical Sciences, 356(2), 90-96 (2018). http://doi.org/10.1016/J.AMJMS.2018.03.015

6. Anderson, HR, Favarato, G, Atkinson, RW.: Long-term exposure to air pollution and the incidence of asthma: meta-analysis of cohort studies. Air Qual Atmos Health 6:47-56 (2013)

7. Badii, M.H., Guillen, A., Abreu, J. L.: Tamaño Óptimo de Muestra en Ciencias Sociales y Naturales Optimal Simple Size (OSS) in Social and Natural Sciences, 9(2), 41-51 (2014).

8. Bai, Y., Sun, Q.: Macrophage recruitment in obese adipose tissue. Obes. Rev. 16, 127-136 (2015). http://dx.doi.org/10.1111/obr.12242

9. Barrett, B., Charles, J. W., Temte, J. L.: Climate change, human health, and epidemiological transition. Preventive Medicine, 70, 69-75 (2015). http://doi.org/10.1016/j.ypmed.2014.11.013

10. Behzad, H., Mineta, K., Gojobori, T., Arabia, S., Arabia, S., Sciences, M., Gojobori, T.: Global Ramifications of Dust and Sandstorm Microbiota. Genome Biology and Evolution, 10(July 2018), 1970-1987 (2018). http://doi.org/10.1093/gbe/evy134/5046809 
11. Bernier, S.A., Gill, T.E., Peterson, R.E.: Climatology of dust in the Southern High Plains of Texas. In: Busacca, A. (Ed.), Proceedings of the International Conference on Dust Aerosols, Loess Soils and Global Change, Seattle, October 1998. Washington State University College of Agriculture and Home Economics Miscellaneous Publication, vol. 190, pp. 4-7 (1998)

12. Bhagia, L. J.: Non-occupational exposure to silica dust. Indian journal of occupational and environmental medicine, 16(3), 95-100 (2012)

13. Bozlaker, A., Peccia, J., Chellam, S.: Indoor/Outdoor Relationships and Anthropogenic Elemental Signatures in Airborne PM2.5 at a High School: Impacts of Petroleum Refining Emissions on Lanthanoid Enrichment. Environmental Science \& Technology, 51(9), 48514859 (2017). https://doi.org/10.1021/acs.est.6b06252

14. Braveman, P. A., Kumanyika, S., Fielding, J., LaVeist, T., Borrell, L. N., Manderscheid, R., Troutman, A.: Health disparities and health equity: The issue is justice. American Journal of Public Health, 101(SUPPL. 1), 149-155 (2011). http://doi.org/10.2105/AJPH.2010.300062

15. Brodie, EL, et al.: Urban aerosols harbor diverse and dynamic bacterial populations. Proc Natl Acad Sci USA. 104(1):299-304 (2007)

16. Brook, R.D., Rajagopalan, S., Pope 3rd, C.A.: Particulate matter air pollution and cardiovascular disease: an update to the scientific statement from the American Heart Association. Circulation 121 (21), 2331-2378 (2010)

17. Brown, E. G., Selma,G., Laybourn, R. L.: Dust Storms and Their Possible Effect on Health. Public Health Reports, 50(40), 20 (1935)

18. Calderón-Garcidueñas, L., Kulesza, R. J., Doty, R. L., D’Angiulli, A., Torres-Jardón, R.: Megacities air pollution problems: Mexico City Metropolitan Area critical issues on the central nervous system pediatric impact. Environmental Research, 137, 157-169 (2015). https://doi.org/10.1016/j.envres.2014.12.012

19. Carvalho-Oliveira, R., Pires-Neto, R. C., Bustillos, J. O., Macchione, M., Dolhnikoff, M., Saldiva, P. H., Garcia, M. L.: Chemical composition modulates the adverse effects of particles on the mucociliary epithelium. Clinics (Sao Paulo, Brazil), 70(10), 706-13 (2015)

20. Chan, Y., Van Nostrand, JD, Zhou, J., Pointing, SB, Farrell, RL.: Functional ecology of an antarctic dry valley. Proc Natl Acad Sci USA. 110(22):8990-8995 (2013)

21. Chan, Y., Teng, J. C., Liu, T., Peng, Y., Chan, Y.: Asian dust storms and diabetes hospitalization: a nationwide population-based study, 1 (2018)

22. Chen, P.S., Tsai, F.T., Lin, C.K., Yang, C.Y., Chan, C.C., Young, C.Y., Lee, C.H.: Ambient influenza and avian influenza virus during dust storm days and background days. Environ. Health Perspective. 118, 1211-1216 (2010)

23. Chiarelli, S. P., Amador Pereira, L. A., Nascimento Saldiva, P. H. do, Ferreira Filho, C., Bueno Garcia, M. L., Ferreira Braga, A. L., Conceição Martins, L.: The association between air pollution and blood pressure in traffic controllers in Santo André, São Paulo, Brazil. Environmental Research, 111(5), 650-5 (2011). https://doi.org/10.1016/j.envres.2011.04.007

24. Chien, L.C., Yang, C.H., Yu, H.L.: Estimated effects of Asian dust storms on spatiotemporal distributions of clinic visits for respiratory diseases in Taipei children (Taiwan). Environ. Health Perspect. 120, 1215e1220 (2012)

25. Chung, H., Sobsey, M.D.: Comparative survival of indicator viruses and enteric viruses in seawater and sediment. Water Sci. Technol. 27, 425-428 (1993)

26. Colls, J.: Air Pollution: Measurement, Modelling and Mitigation, Second Edition. London: CRC Press (2002)

27. Cooper, L. A., Purnell, T. S., Ibe, C. A., Halbert, J. P., Bone, L. R., Carson, K. A., Levine, D. M.: Reaching for Health Equity and Social Justice in Baltimore: The Evolution of an Academic-Community Partnership and Conceptual Framework to Address Hypertension Disparities. Ethnicity \& Disease, 26(3), 369-78 (2016). http://doi.org/10.18865/ed.26.3.369 
28. Cox, C.S.: Stability of Airborne Microbes and Allergens. In: Cox, C.S., Wathes, C.M. (Eds.), Bioaerosols Handbook. Lewis Publishers, London, UK (1995)

29. Despres, V. R., Huffman, J. A., Burrows, S. M., Hoose, C., Safatov, A. S., Buryak, G., Frohlich-Nowoisky, J., Elbert, W., Andreae, M. O., Pöschl, U., Jaenicke, R.: Primary biological aerosol particles in the atmosphere: a review, Tellus Ser. B, 64, 15598, doi:10.3402/tellusb.v64i0.15598 (2012)

30. Dostert, C., Pétrilli, V., Van Bruggen, R., Steele, C., Mossman, B. T., Tschopp, J.: Innate immune activation through Nalp3 inflammasome sensing of asbestos and silica. Science, 320(5876), 674-677 (2008). http://doi.org/10.1126/science.1156995

31. Ebrahimi, S. J. A., Ebrahimzadeh, L., Eslami, A., Bidarpoor, F.: Effects of dust storm events on emergency admissions for cardiovascular and respiratory diseases in Sanandaj, Iran. Journal of Environmental Health Science and Engineering, 12(1), 1-5 (2014). http://doi.org/10.1186/s40201-014-0110-x

32. EPA Homepage. Criteria Air Pollutants. Retrieved from https://www.epa.gov/criteria-airpollutants/naaqs-table, last accessed 2018/1/9.

33. EPA Homepage, Reference News Release: Oil Refiners to Reduce Air Pollution at Six Refineries Under Settlement with EPA and Department of Justice. Retrieved from https://www.epa.gov/enforcement/reference-news-release-oil-refiners-reduce-air-pollution-six-refineries-under-settlement, last accessed 2018/7/20.

34. EPA b Homepage, Criteria Air Pollutants. Retrieved from https://www.epa.gov/criteria-airpollutants/naaqs-table, last accessed 2018/1/9)

35. Etemadifar Z, Gholami M, Derikvand P.: UV-resistant bacteria with multiple-stress tolerance isolated from desert areas in Iran. Geomicrobiol J. 33(7):1-598 (2016)

36. Finkel, M. L.: The impact of oil sands on the environment and health. Environmental Science \& Health, 3, 52-55 (2018). https://doi.org/10.1016/J.COESH.2018.05.002

37. Franchini, M., Mannucci, P. M.: Inhibitors of propagation of coagulation (factors VIII, IX and XI): A review of current therapeutic practice. British Journal of Clinical Pharmacology, 72(4), 553-562 (2011). http://doi.org/10.1111/j.1365-2125.2010.03899.x

38. Franzetti, A, Gandolfi, I, Gaspari, E, Ambrosini, R, Bestetti, G.: Seasonal variability of bacteria in fine and coarse urban air particulate matter. Appl Microbiol Biotechnol. 90(2):745$753(2011)$

39. Fuzzi, S., Baltensperger, U., Carslaw, K., Decesari, S., Denier Van Der Gon, H., Facchini, M. C., Gilardoni, S.: Particulate matter, air quality and climate: Lessons learned and future needs. Atmospheric Chemistry and Physics, 15(14), 8217-8299 (2015). http://doi.org/10.5194/acp-15-8217-2015

40. Garcia, G. J. M., Schroeter, J. D., Kimbell, J. S.: Olfactory deposition of inhaled nanoparticles in humans. Inhalation Toxicology, 27(8), 394-403 (2015). http://doi.org/10.3109/08958378.2015.1066904

41. García, J. H., Li, W.-W., Arimoto, R., Okrasinski, R., Greenlee, J., Walton, J., Sage, S.: Characterization and implication of potential fugitive dust sources in the Paso del Norte region. Science of the Total Environment, 325(1), 95-112 (2004). http://doi.org/10.1016/j.scitotenv.2003.11.011

42. Gee, G. C., Walsemann, K. M., Brondolo, E.: A life course perspective on how racism may be related to health inequities. American Journal of Public Health, 102(5), 967-974 (2012). http://doi.org/10.2105/AJPH.2012.300666

43. Ghio, A. J., Huang, Y.-C. T.: Exposure to Concentrated Ambient Particles (CAPs): A Review. Inhalation Toxicology, 16(1), 53-59 (2004). http://doi.org/10.1080/08958370490258390

44. Gill, T.E., Stout, J.E., Peinado, P.: Composition and characteristics of aerosols in the Southern High Plains of Texas, USA. AIP Conference Proceedings 1099: 255- 258 (2009) 
45. Ginoux, P., Prospero, J., Gill, T., Hsu, N., Zhao, M.: Globalscale attribution of anthropogenic and natural dust sources and their emission rates based on modis deep blue aerosol products, Rev. Geophys., 50, RG3005 (2012). http://doi:10.1029/2012RG000388.

46. Global Change Homepage, https://health2016.globalchange.gov/report-guide\#figure-90, last accessed 2017/1/6

47. Griffin, D.W.: Atmospheric movement of microorganisms in clouds of desert dust and implications for human health. Clin. Microbiol. Rev. 20, 459-477 (2007)

48. Grineski, S. E., Herrera, J. M., Bulathsinhala, P., Staniswalis, J. G.: Is there a Hispanic Health Paradox in sensitivity to air pollution? Hospital admissions for asthma, chronic obstructive pulmonary disease and congestive heart failure associated with NO2 and PM2.5 in El Paso, TX, 2005-2010. Atmospheric Environment, 119, 314-321 (2015). http://doi.org/10.1016/j.atmosenv.2015.08.027

49. Grineski, S. E., Staniswalis, J. G., Bulathsinhala, P., Peng, Y., Gill, T. E.: Hospital admissions for asthma and acute bronchitis in El Paso, Texas: Do age, sex, and insurance status modify the effects of dust and low wind events? Environmental Research, 111(8), 11481155 (2011). http://doi.org/10.1016/j.envres.2011.06.007

50. Gurgueira, S.A., Lawrence, J., Coull, B., Murthy, G., Gonzalez-Flecha, B.: Rapid increases in the steady-state concentration of reactive oxygen species in the lungs and heart after particulate air pollution inhalation. Environ. Health Perspect. 110, 749-755 (2002). http://dx.doi.org/10.1289/ehp.02110749

51. Halonen, J. I., Blangiardo, M., Toledano, M. B., Fecht, D., Gulliver, J., Anderson, H. R., Tonne, C.: Long-term exposure to traffic pollution and hospital admissions in London. Environmental Pollution (Barking, Essex: 1987), 208( $\mathrm{Pt}$ A), $48-57$ (2016). https://doi.org/10.1016/j.envpol.2015.09.051

52. Hansen, J, Sato, M, Ruedy, R, Lo, K, Lea, DW, Medina-Elizade, M.: Global temperature change. Proc Natl Acad Sci USA;103:14288-93 (2006)

53. Heusinkveld, H. J., Wahle, T., Campbell, A., Westerink, R. H. S., Tran, L., Johnston, H., ,.. Schins, R. P. F.: Neurodegenerative and neurological disorders by small inhaled particles. NeuroToxicology, 56, 94-106 (2016). http://doi.org/10.1016/j.neuro.2016.07.007

54. Holliday, V.T.: The Blackwater Draw Formation (Quaternary): a 1.4-plus-m.y. record of aeolian sedimentation and soil formation on the Southern High Plains. Geol. Soc. Am. Bull. 101, 1598-1607 (1989)

55. Hosiokangas, J., Vallius, M., Ruuskanen, J., Mirme, A., Pekkanen, J.: Resus- pended dust episodes as an urban air-quality problem in subarctic regions. Scandinavian Journal of Work and Environmental Health 30, 28-35 (2004)

56. Howard, G., Peace, F., Howard, V. J.: The contributions of selected diseases to disparities in death rates and years of life lost for racial/ethnic minorities in the United States, 19992010. Preventing Chronic Disease, 11, E129 (2014). http://doi.org/10.5888/pcd11.140138

57. Huang, M, Wang, W, Chan, CY, Cheung, KC, Man, YB, Wang, X, et al.: Contamination and risk assessment (based on bioaccessibility via ingestion and inhalation) of metal(loid)s in outdoor and in- door particles from urban centers of Guangzhou, China. Sci Total Environ;479-480:117-124 (2014)

58. Husar, RB, et al.: Asian dust events of April 1998. J Geophys Res. 106(D16):18317-18330 (2001)

59. Intergovernmental Panel on Climate Change (IPCC) a: Climate Change 2007: Impacts, Adaptation and Vulnerability. In: Parry, M.L., Canziani, O.F., Palutikof, J.P., van der Linden, P.J., Hanson, C.E. (Eds.), Contribution of Working Group II to the Fourth Assessment Report of the Intergovernmental Panel on Climate Change. Cambridge University Press, Cambridge, UK (2007a)

60. Intergovernmental Panel on Climate Change (IPCC) b: Climate change 2007: impacts, adaptation and vulnerability contribution of Working Group II to the Fourth Assess- ment 
Report of the Intergovernmental Panel on Climate Change. In: Parry ML, Canzani OP, Palutikof JP, et al, editors. Cambridge, New York: Cambridge University Press (2007)

61. Jacob, D. J., Darrel, A.: (2009). Effect of climate change on air quality. Atmospheric Environment 43(1): 51-63 (2007b)

62. Kanatani, K. T., Ito, I., Al-Delaimy, W. K., Adachi, Y., Mathews, W. C., Ramsdell, J. W., Yamamoto, J.: Desert dust exposure is associated with increased risk of asthma hospitalization in children. American Journal of Respiratory and Critical Care Medicine, 182(12), 1475-1481 (2010). http://doi.org/10.1164/rccm.201002-0296OC

63. Kaplan, R. M.: Behavior change and reducing health disparities. Preventive Medicine, 68, 5-10 (2014). http://doi.org/10.1016/j.ypmed.2014.04.014

64. Karagulian, F., Belis, C. A., Dora, C. F. C., Prüss-Ustün, A. M., Bonjour, S., Adair-Rohani, H., Amann, M.: Contributions to cities' ambient particulate matter (PM): A systematic review of local source contributions at global level. Atmospheric Environment, 120, 475-483 (2015). http://doi.org/10.1016/j.atmosenv.2015.08.087

65. Karanasiou, A., Moreno, N., Moreno, T., Viana, M., de Leeuw, F., Querol, X.: Health effects from Sahara dust episodes in Europe: Literature review and research gaps, Environment Int., 47, 107-114 (2012). doi:10.1016/j.envint.2012.06.012

66. Keil, D. E., Buck, B., Goossens, D., McLaurin, B., Murphy, L., Leetham-Spencer, M., DeWitt, J. C.: Nevada desert dust with heavy metals suppresses IgM antibody production. Toxicology Reports, 5(June 2017), 258-269 (2018). http://doi.org/10.1016/j.toxrep.2018.01.006

67. Keil, D. E., Buck, B., Goossens, D., Teng, Y., Pollard, J., McLaurin, B., DeWitt, J.: Health effects from exposure to atmospheric mineral dust near Las Vegas, NV, USA. Toxicology Reports, 3, 785-795 (2016). http://doi.org/10.1016/j.toxrep.2016.09.009

68. Keil, D.E., Buck, B., Goossens, D., Teng, Y., Spencer, M., Murphy, L., Pollard, J., Eggers, M., McLaurin, B., Gerads, R., DeWitt, J.: Immunotoxicological and neurotoxicological profile of health effects following subacute exposure to geogenic dust from sand dunes at the Nellis Dunes Recreation Area Las Vegas, NV. Toxicol. Appl. Pharmacol. 2016;291:1-12 (2016)

69. Khan, R. K., Strand, M. A.: Road dust and its effect on human health: a literature review. Epidemiology and health, 40, e2018013(2018). Doi:10.4178/epih.e2018013

70. Khaniabadi, Y. O., Fanelli, R., De Marco, A., Daryanoosh, S. M., Kloog, I., Hopke, P. K., Goudarzi, G. (2017). Hospital admissions in Iran for cardiovascular and respiratory diseases attributed to the Middle Eastern Dust storms. Environmental Science and Pollution Research, 24(20), 16860-16868. http://doi.org/10.1007/s11356-017-9298-5

71. Kinge, J. M., Steingrímsdóttir, Ó. A., Strand, B. H., Kravdal, Ø.: Can socioeconomic factors explain geographic variation in overweight in Norway? SSM - Population Health, 2, 333340 (2016). http://doi.org/https://doi.org/10.1016/j.ssmph.2016.04.010

72. Kioumourtzoglou, M. A., Schwartz, J. D., Weisskopf, M. G., Melly, S. J., Wang, Y., Dominici, F., Zanobetti, A.: Long-term PM Exposure and Neurological Hospital Admissions in the Northeastern United States. Environmental Health Perspectives, 124(1), 23-29 (2015). http://doi.org/10.1289/ehp.1408973

73. Kirkland, TN, Fierer, J.: Coccidioidomycosis: a reemerging infectious disease. Emerg Infect Dis. 2(3):192-199 (1996)

74. Krieger, N.: Living and Dying at the Crossroads: Racism, Embodiment, and Why Theory Is Essential for a Public Health of Consequence. American Journal of Public Health, 106(5), 832-833 (2016). http://doi.org/10.2105/AJPH.2016.303100

75. Lee, J. A., Gill, T. E.: Multiple causes of wind erosion in the Dust Bowl. Aeolian Research, 19(November 2006), 15-36 (2015). http://doi.org/10.1016/j.aeolia.2015.09.002

76. Lee, J. A., Baddock, M. C., Mbuh, M. J., Gill, T. E.: Geomorphic and land cover characteristics of aeolian dust sources in West Texas and eastern New Mexico, USA. Aeolian Research, 3(4), 459-466 (2012). http://doi.org/10.1016/j.aeolia.2011.08.001 
77. Lee, J. A., Gill, T. E., Mulligan, K. R., Dominguez Acosta, M., Perez, A. E.: Land use/land cover and point sources of the 15 December 2003 dust storm in southwestern North America. Geomorphology, 105(1-2), 18-27 (2009). https://doi.org/10.1016/j.geomorph.2007.12.016

78. Lee, J., Baddock, M., Mbuh, M., Gill, T.: Geomorphic and land cover characteristics of aeolian dust sources in West Texas and eastern New Mexico, USA. Aeolian Research (Vol. 3) (2012). http://doi.org/10.1016/j.aeolia.2011.08.001

79. Lee, J.A., Tchakerian, V.P.: Magnitude and frequency of blowing dust on the Southern High Plains of the United States, 1947-1989. Ann. Assoc. Am. Geogr. 85, 684-693 (1995).

80. Li, J., Kandakji, T., Lee, J. A., Tatarko, J., Blackwell, J., Gill, T. E., Collins, J. D.: Blowing dust and highway safety in the southwestern United States: Characteristics of dust emission "hotspots" and management implications. Science of The Total Environment, 621, 10231032 (2018). http://doi.org/10.1016/J.SCITOTENV.2017.10.124

81. Li, R., Kou, X., Geng, H., Xie, J., Tian, J., Cai, Z., Dong, C.: Mitochondrial damage: an important mechanism of ambient PM2.5 exposure-induced acute heart injury in rats. Journal of Hazardous Materials, 287, 392-401 (2015). https://doi.org/10.1016/j.jhazmat.2015.02.006

82. Li, W.-W., Orquiz, R., Garcia, J. H., Espino, T., Pingitore, N. E., Gardea-Torresdey, J., Watson, J. G.: Analysis of temporal and spatial dichotomous PM air samples in the El PasoCd. Juarez air quality basin. Journal of the Air \& Waste Management Association (1995), 51(11), 1551-60 (2001). http://doi.org/10.1080/10473289.2001.10464377

83. Lim, J.Y., Chun, Y.: The characteristics of Asian dust events in Northeast Asia during the springtime from 1993 to 2004. Global and Planetary Change, 52, 231-247 (2006)

84. Ma, Y., Zhang, H., Zhao, Y., Zhou, J., Yang, S., Zheng, X., Wang, S.: Short-term effects of air pollution on daily hospital admissions for cardiovascular diseases in western China. Environmental Science and Pollution Research, 24(16), 14071-14079 (2017). http://doi.org/10.1007/s11356-017-8971-z

85. Middleton, N. J: Desert dust hazards: A global review. Aeolian Research, 24, 53-63 (2017). https://doi.org/https://doi.org/10.1016/j.aeolia.2016.12.001

86. Morman, S. A., Plumlee, G. S.: The role of airborne mineral dusts in human disease. Aeolian Research, 9, 203-212 (2013). http://doi.org/10.1016/j.aeolia.2012.12.001

87. Morman, S.A., Plumlee, G.S.: Dust and human health. In Mineral Dust (pp. 385-409). Springer, Dordrecht (2014)

88. Nemmar, A., Al-Salam, S., Zia, S., Dhanasekaran, S., Shudadevi, M., Ali, B. H.: Timecourse effects of systemically administered diesel exhaust particles in rats. Toxicology Letters, 194(3), 58-65 (2010). http://doi.org/10.1016/J.TOXLET.2010.02.001

89. Nemmar, A., Hoylaerts, M. F., Hoet, P. H.., Vermylen, J., Nemery, B.: Size effect of intratracheally instilled particles on pulmonary inflammation and vascular thrombosis. Toxicology and Applied Pharmacology, 186(1), 38-45 (2003). https://doi.org/10.1016/S0041008X(02)00024-8

90. Nery, L. E., Florencio, R. T., Sandoval, P. R. M., Rodrigues, R. T., Alonso, G., Mason, G. R.: Additive effects of exposure to silica dust and smoking on pulmonary epithelial permeability: A radioaerosol study with technetium-99m labelled DTPA. Thorax, 48(3), 264-268 (1993). http://doi.org/10.1136/thx.48.3.264

91. Novlan, D. J., Hardiman, M., Gill, T. E.: A Synoptic Climatology of Blowing Dust Events in El Paso, Texas from 1932-2005. American Meteorological Society J., 3 (2007)

92. O’Neill, L. A. J., Dunne, A.: The Interleukin-1 Receptor / Toll-Like Receptor Superfamily, (February), 1-18 (2008)

93. Oberdörster, G., Sharp, Z., Atudorei, V., Elder, A., Gelein, R., Kreyling, W., Cox, C.: Translocation of inhaled ultrafine particles to the brain. Inhalation Toxicology, 16(6-7), 437-445 (2004). https://doi.org/10.1080/08958370490439597 
94. Oil Change International Homepage, Refineries, http://refineryreport.org/refineries.php, last accessed 2018/7/5

95. Olvera, H. A., Kubzansky, L. D., Campen, M. J., Slavich, G. M.: Neuroscience and Biobehavioral Reviews Early life stress, air pollution, inflammation, and disease: An integrative review and immunologic model of social-environmental adversity and lifespan health. Neuroscience and Biobehavioral Reviews, 92(May), 226-242 (2018). https://doi.org/10.1016/j.neubiorev.2018.06.002

96. Orgill M.M., Sehmel G.A.: Frequency and diurnal variation of dust storms in the contiguous U.S.A. Atmospheric Environment, 10 pp. 813-825 (1976)

97. Prospero, J.M., Ginoux, P., Torres, O., Nicholson, S.E., Gill, T.E.: Environmental characterization of global sources of atmospheric soil dust identified with the nimbus 7 total ozone mapping spectrometer (toms) absorbing aerosol product. Reviews of Geophysics 40: doi: 10.1029/2000RG000095. issn: 8755-1209 (2002)

98. Prussin A. J., Garcia E. B., Marr L. C.: Total concentrations of virus and bacteria in indoor and outdoor air. Environ Sci Tech Lett. 2(4):84-88 (2015)

99. Reynolds, K., Go, A. S., Leong, T. K., Boudreau, D. M., Cassidy-bushrow, A. E., Fortmann, S. P., Sidney, S.: Trends in Incidence of Hospitalized Acute Myocardial Infarction in the Cardiovascular Research Network (CVRN). The American Journal of Medicine (2016). http://doi.org/10.1016/j.amjmed.2016.09.014

100. Rivas, Jose A. Jr., Thomas E. Gill, Elizabeth J. Walsh, Robert L. Wallace.: Characterization of Dust Transported to El Paso, Texas. Abstracts of the 18th Joint Conference on the Applications of Air Pollution Meteorology with the A\&WMA, American Meteorological Society Annual Meeting, Atlanta, GA, February 2014, Abstract \# 236614 (2014)

101. Rivera Rivera, N. I., Gill, T. E., Gebhart, K. A., Hand, J. L., Bleiweiss, M. P., Fitzgerald, R. M.: Wind modeling of Chihuahuan Desert dust outbreaks. Atmospheric Environment, 43(2), 347-354 (2009). http://doi.org/10.1016/j.atmosenv.2008.09.069

102. Rivera, N. I. R., Gill, T. E., Bleiweiss, M. P., Hand, J. L.: Source characteristics of hazardous Chihuahuan Desert dust outbreaks. Atmospheric Environment, 44(20), 2457-2468 (2010). https://doi.org/10.1016/J.ATMOSENV.2010.03.019

103. Rodo X, et al.: Tropospheric winds from northeastern china carry the etiologic agent of Kawasaki disease from its source to japan. Proc Natl Acad Sci USA. 111(22):79527957(2014).

104. Rodopoulou, S., Chalbot, M. C., Samoli, E., DuBois, D. W., San Filippo, B. D., Kavouras, I. G.: Air pollution and hospital emergency room and admissions for cardiovascular and respiratory diseases in Doña Ana County, New Mexico. Environmental Research, 129, 3946 (2014). http://doi.org/10.1016/j.envres.2013.12.006

105. Schwarze, P.E., Totlandsdal, A.I., Låg, M., Refsnes, M., Holme, J.A., Øvrevik, J.: Inflammation-related effects of diesel engine exhaust particles: studies on lung cells in vitro. Biomed. Res. Int. 2013, 1-13 (2013). http://dx.doi.org/10.1155/2013/685142

106. Schweitzer, M. D., Calzadilla, A. S., Salamo, O., Sharifi, A., Kumar, N., Holt, G., Mirsaeidi, M.: Lung health in era of climate change and dust storms. Environmental Research, 163(February), 36-42 (2018). http://doi.org/10.1016/j.envres.2018.02.001

107. Shao, Y.: Physics and modelling of wind erosion (2nd edn.). Heidelberg: Springer (2008)

108. Shrey, K., Suchit, A., Deepika, D., Shruti, K., Vibha, R.: Air pollutants: the key stages in the pathway towards the development of cardiovascular disorders. Environmental Toxicology and Pharmacology, 31(1), 1-9 (2011). http://doi.org/10.1016/j.etap.2010.09.002

109. Song, Z., Wang, J., Wang, S.: Quantitative classification of northeast Asian dust events. Journal of Geophysical Research, 112(D4), D04211 (2007). http://doi.org/10.1029/2006JD007048

110. Sujaritpong, S., Dear, K., Cope, M., Walsh, S., Kjellstrom, T.: Quantifying the health impacts of air pollution under a changing climate-a review of approaches and methodology. 
Estrella Molina-Herrera, Alberto Ochoa, Thomas Gill, Gabriel Ibarra-Mejia, Carlos Herrera

International Journal of Biometeorology, 58(2), 149-160 (2014). http://doi.org/10.1007/s00484-012-0625-8

111. Sun, J., Fu, J. S., Huang, K., Gao, Y.: Estimation of future PM2.5- and ozone-related mortality over the continental United States in a changing climate: An application of high-resolution dynamical downscaling technique. Journal of the Air \& Waste Management Association, 65(5), 611-623 (2015). http://doi.org/10.1080/10962247.2015.1033068

112. Tang K, et al.: Characterization of atmospheric bioaerosols along the transport pathway of Asian dust during the dust-bioaerosol 2016 campaign. Atmos Chem Phys. 18:7131-7148 (2018). doi: 10.5194/acp-18-7131

113. Tarhan, C., Ozcan, N. S., Ozkan, S. P.: The Relationship between Respiratory Systems' Cases and Environmental Urban Factors. Procedia - Social and Behavioral Sciences, 216, 622-631 (2016). http://doi.org/10.1016/j.sbspro.2015.12.040

114. Texas Climate Descriptions Homepage, http://web2.airmail.net/danb1/texas_climate_descriptions.htm, last accessed 2016/2/6

115. Tili, E., Michaille, J.-J., Wernicke, D., Alder, H., Costinean, S., Volinia, S., Croce, C. M.: Mutator activity induced by microRNA-155 (miR-155) links inflammation and cancer. Proceedings of the National Academy of Sciences of the United States of America, 108(12), 4908-13 (2011). http://doi.org/10.1073/pnas.1101795108

116. Tong DQ, Wang JXL, Gill TE, Lei H, Wang BY.: Intensified dust storm activity and valley fever infection in the southwestern United States. Geophys Res Lett. 44(9):4304-4312 (2017).

117. Tonne, C., Halonen, J. I., Beevers, S. D., Dajnak, D., Gulliver, J., Kelly, F. J., Anderson, H. R.: Long-term traffic air and noise pollution in relation to mortality and hospital readmission among myocardial infarction survivors. International Journal of Hygiene and Environmental Health, 219(1), 72-78 (2016). https://doi.org/10.1016/j.ijheh.2015.09.003

118. Touloumi, G., Atkinson, R., Le Tertre, A., Samoli, E., Schwartz, J., Schindler, C., et al.: Analysis of health outcome time series data in epidemiological studies. Environmetrics 15, 101-117 (2004)

119. Van Pelt, R. S., Zobeck, T. M.: Chemical constituents of fugitive dust. Environmental Monitoring and Assessment, 130(1-3), 3-16 (2007). http://doi.org/10.1007/s10661-006-9446-8

120. Vineis, P., Foraster, F., Hoek, G., Lippsett, M.: Outdoor air pollution and lung cancer: recent epidemiological evidence. Int. J. Cancer 111, 647e652 (2004)

121. Wang Y, et al.: Effects of dust storm events on weekly clinic visits related to pulmonary tuberculosis disease in Minqin, China. Atmos Environ. 127:205-212 (2016)

122. Weil T, et al.: Legal immigrants: invasion of alien microbial communities during winter occurring desert dust storms. Microbiome 5(1):32 (2017)

123. Weintraub, D., Xie, S., Karlawish, J., Siderowf, A.: Differences in depression symptoms in patients with Alzheimer's and Parkinson's diseases: evidence from the 15-item Geriatric Depression Scale (GDS-15). International journal of geriatric psychiatry, 22(10), 1025-30 (2007)

124. Wolf, K., Schneider, A., Breitner, S., Meisinger, C., Heier, M., Cyrys, J., Peters, A.: Associations between short-term exposure to particulate matter and ultrafine particles and myocardial infarction in Augsburg, Germany. International Journal of Hygiene and Environmental Health, 218(6), 535-42 (2015). https://doi.org/10.1016/j.ijheh.2015.05.002

125. Wu, S., Ni, Y., Li, H., Pan, L., Yang, D., Baccarelli, A. A., Guo, X.: Short-term exposure to high ambient air pollution increases airway inflammation and respiratory symptoms in chronic obstructive pulmonary disease patients in Beijing, China. Environ Int, 94, 76-82 (2016). https://doi.org/10.1016/j.envint.2016.05.004

126. Yu, H. L., Chien, L. C., Yang, C. H.: Asian dust storm elevates children's respiratory health risks: A spatiotemporal analysis of children's clinic visits across Taipei (Taiwan). PLoS ONE, 7(7), 1-9 (2012). http://doi.org/10.1371/journal.pone.0041317 
Conceptualization of a Predictive Model for Analysis of the Health Outcomes of Dust Events...

127. Zablocki O, Adriaenssens EM, Cowan D.: Diversity and ecology of viruses in hyperarid desert soils. Appl Environ Microbiol. 82(3):770-777 (2016)

128. Zhang, X., Zhao, L., Tong, Q. D., Wu, G., Dan, M., Teng, B.: A Systematic Review of Global Desert Dust and Associated Human Health Effects. Atmosphere (2016). http://doi.org/10.3390/atmos7120158 